\title{
Proteomics of Two Thermotolerant Isolates of Trichoderma under High-Temperature Stress
}

\author{
Sowmya Poosapati ${ }^{1,2, * \mathbb{C}}$, Prasad Durga Ravulapalli ${ }^{1}$, Dinesh Kumar Viswanathaswamy ${ }^{3}$ and Monica Kannan ${ }^{4}$ \\ 1 Department of Plant Pathology, ICAR-Indian Institute of Oilseeds Research, Rajendranagar, \\ Hyderabad 500030, India; ravulapalliprasad@gmail.com \\ 2 Section of Cell and Developmental Biology, University of California San Diego, La Jolla, CA 92093, USA \\ 3 Department of Biotechnology, ICAR-Indian Institute of Oilseeds Research Rajendranagar, \\ Hyderabad 500030, India; dineshkumarv@yahoo.com \\ 4 Proteomics Facility, School of Life Sciences, University of Hyderabad, Gachibowli, Hyderabad 500046, India; \\ monica_kannan2001@yahoo.co.in \\ * Correspondence: spoosapati@ucsd.edu
}

Citation: Poosapati, S.; Ravulapalli, P.D.; Viswanathaswamy, D.K.; Kannan, M. Proteomics of Two Thermotolerant Isolates of Trichoderma under High-Temperature Stress. J. Fungi 2021, 7, 1002. https:// doi.org/10.3390/jof7121002

Academic Editor: Willem Melchers

Received: 3 November 2021

Accepted: 22 November 2021

Published: 24 November 2021

Publisher's Note: MDPI stays neutral with regard to jurisdictional claims in published maps and institutional affiliations.

Copyright: (c) 2021 by the authors. Licensee MDPI, Basel, Switzerland. This article is an open access article distributed under the terms and conditions of the Creative Commons Attribution (CC BY) license (https:// creativecommons.org/licenses/by/ $4.0 /)$.

\begin{abstract}
Several species of the soil borne fungus of the genus Trichoderma are known to be versatile, opportunistic plant symbionts and are the most successful biocontrol agents used in today's agriculture. To be successful in field conditions, the fungus must endure varying climatic conditions. Studies have indicated that a high atmospheric temperature coupled with low humidity is a major factor in the inconsistent performance of Trichoderma under field conditions. Understanding the molecular modulations associated with Trichoderma that persist and deliver under abiotic stress conditions will aid in exploiting the value of these organisms for such uses. In this study, a comparative proteomic analysis, using two-dimensional gel electrophoresis (2DE) and matrix-assisted laser desorption/time-of-flight (MALDI-TOF-TOF) mass spectrometry, was used to identify proteins associated with thermotolerance in two thermotolerant isolates of Trichoderma: T. longibrachiatum 673, TaDOR673 and T. asperellum 7316, TaDOR7316; with 32 differentially expressed proteins being identified. Sequence homology and conserved domains were used to identify these proteins and to assign a probable function to them. The thermotolerant isolate, TaDOR673, seemed to employ the stress signaling MAPK pathways and heat shock response pathways to combat the stress condition, whereas the moderately tolerant isolate, TaDOR7316, seemed to adapt to high-temperature conditions by reducing the accumulation of misfolded proteins through an unfolded protein response pathway and autophagy. In addition, there were unique, as well as common, proteins that were differentially expressed in the two isolates studied.
\end{abstract}

Keywords: Trichoderma; thermotolerance; cell wall remodeling; MAPK; Hsf1; UPR; autophagy

\section{Introduction}

Fungi belonging to the genus Trichoderma account for more than $60 \%$ of all registered biopesticides [1]. Trichoderma is used to antagonize phytopathogenic fungi, and the antifungal properties of Trichoderma are principally due to their ability to produce antibiotics [2] and/or hydrolytic enzymes [3] and owing to competition for space and nutrients [4]. Even if Trichoderma species can promote plant growth and induce resistance to biotic and abiotic stresses [5,6], their role as a bio-pesticide has primarily contributed to their commercial success as bio-agents. Nevertheless, Trichoderma by themselves are not immune to abiotic stresses such as moisture deficiency, higher temperature, etc., which tend to cause morphological, physiological, biochemical, and molecular changes and adversely affect the beneficial results of these bioagents. For example, soil hydrological conditions influences the growth and antagonistic properties of Trichoderma $[7,8]$ and soil temperature affects the radial extension of this fungus [9]. 
Furthermore, agricultural practices such as solarization of the soil have been widely used to eradicate infectious pathogens from soil [10], as these practices weaken the potential of pathogens to damage crops and increase their susceptibility to bio-agents. Such practices also subject Trichoderma, if applied to the soil, to high-temperature stress. Therefore, there is a synergistic benefit in combining sub-lethal solarization with thermotolerant bioagents, especially Trichoderma, to suppress crop-damaging, temperature-tolerant pathogens in soil [11,12].

Thermotolerant strains have been identified in Bacillus, Pseudomonas, and Beauveria bassiana $[13,14]$, but as Trichoderma is already a widely used bio-agent, the identification of thermotolerant strains of this genus would be relevant, apart from the economic significance entailed [15]. Advancements in the 'omics' sciences have enabled researchers to understand the mechanisms of thermotolerance in organisms such as Saccharomyces cerevisiae, Metarhizium sp. etc. [16-19], and this information has been exploited to improve the strains and stress resistance in plants [20-22]. In Trichoderma, specifically, the hog 1 gene (ThHog1) from the MAPK pathway was the first to be implicated in tolerance to osmotic stress [23]. Molecular studies have revealed that components of the cell wall undergo a dynamic change to adapt to stress conditions [24,25] and act as mediators of stress response [26-28], to activate the cell wall integrity (CWI) MAPK pathway [29,30]. Specifically, Protein kinase $\mathrm{C}(\mathrm{Pkc})$ is implicated in the maintenance of cell wall integrity (CWI) in response to different environmental stresses [31].

Fungi are known to develop different strategies, involving diverse regulatory mechanisms, to adapt to stress conditions. Heat shock response is a highly conserved pathway that results in the immediate synthesis of a pool of cytoprotective genes in the presence of diverse environmental stresses. The accumulation of misfolded proteins rapidly activates Hsf1 [18,32,33], which in turn induces several heat shock proteins that help in the proper folding of misfolded proteins during stress conditions [34,35]. The role of Hsf1 in cell wall remodeling [36] indicated a cross-talk between stress induced pathways. Only a few researchers have evaluated the role of Trichoderma-derived heat shock proteins in tolerance to heat, salt, and oxidative stress [20,21]. In a recent report, it was observed that elevated levels of heat shock protein from T. asperellum, TaHsp70c were specifically produced during heat and cold stress [37]. Other genes, such as glutathione transferase [38] and proteins with glucosidase activity [39], were also shown to enhance tolerance to several abiotic stresses. The studies were highly focused on understanding the effect of various stresses in pathogenic fungi of clinical importance [35,40-42]. Nevertheless, researchers have reviewed the role of various Trichoderma genes in plant stress tolerance [22].

In spite of the growing genomic resources in Trichoderma species (the genomes of several Trichoderma species have been sequenced [https://jgi.doe.gov/search-results/?q= trichoderma, accessed on 31 October 2021] and ESTs from several species of Tricho derma being available in the TrichoEST database $[43,44]$, much of the research so far has focused on studies involving plant-pathogen-bioagent interactions [45], mycoparasitim [46], biocontrol related genes and enzymes [47,48], and proteases produced by bio-agents [3,49-51]. But there are only a few reports on the molecular changes associated with heat stress conditions in Trichoderma [52].

In the present investigation, we used two thermotolerant Trichoderma strains identified previously in our lab [15], and which differed in their level of tolerance to temperature stress. Proteins that were differentially expressed when subjected to temperature stress were identified using 2D electrophoresis and MALDI-TOF. To the best of our knowledge, this is the first report of a proteomic analysis of heat stress response in thermotolerant Trichoderma species. 


\section{Materials and Methods}

\subsection{Strains}

The thermotolerant strains of Trichoderma viz., T. longibrachiatum 673, TaDOR673 and T. asperellum 7316, TaDOR7316, which had been identified previously [15], were used for this study. These strains are deposited and maintained in the microbial type culture collection (MTCC), IMTECH, Chandigarh, India. These thermotolerant strains were identified from a pool of Trichoderma isolates obtained from soil samples collected from various regions of India. To confirm their identity, multi-locus sequencing (Internal transcribed spacer 1 (ITS1), elongation factor1 alpha, and RNA polymerase subunit B) was performed, and the results confirmed the identity of these strains (accession numbers are provided in Table S1).

\subsection{Growth Conditions}

The strains were grown on potato dextrose agar at $28^{\circ} \mathrm{C}$ for 7 days. Briefly, $2-3$ mycelial discs from a 7-day-old culture were used to inoculate $100 \mathrm{~mL}$ of potato dextrose broth in $250 \mathrm{~mL}$ Erlenmeyer flasks and were incubated for 3 days at $28^{\circ} \mathrm{C}$ and $200 \mathrm{rpm}$, followed by incubation in a static position for 4 days to allow better sporulation. Two biological replicates were used and the cultures were exposed to a temperature of $48{ }^{\circ} \mathrm{C}$ for $1 \mathrm{~h}$ and $4 \mathrm{~h}$ (treated samples). After incubation, mycelium was filtered and frozen in liquid nitrogen and stored at $-80{ }^{\circ} \mathrm{C}$ until use. Samples from both strains that were not subjected to thermal stress were used as control.

\subsection{Protein Extraction}

The protein extraction protocol described by Jacobs et al. [53] was followed, with a few modifications. In brief, approximately $1 \mathrm{~g}$ of fungal mycelium was ground in liquid nitrogen and suspended in $10 \mathrm{~mL}$ of cold $\left(-20^{\circ} \mathrm{C}\right)$ acetone solution, containing $13.3 \%$ Trichloroacetic acid (TCA) and $0.07 \%$ ß-mercaptoethanol. Samples were vortexed and maintained at $-20{ }^{\circ} \mathrm{C}$ for at least $3 \mathrm{~h}$, with intermittent shaking to allow the precipitation of protein, and then centrifuged at 14,000 rpm for $20 \mathrm{~min}$ at $4^{\circ} \mathrm{C}$. The pellets were washed three times with cold $\left(-20^{\circ} \mathrm{C}\right)$ acetone solution containing $0.07 \% \AA$-mercaptoethanol and air dried. The pellets were resuspended in labeling buffer (8 M urea, $2 \mathrm{M}$ thiourea, 2\% 3[(3-cholamidopropyl)-dimethyl-ammonio]-1-propane sulfonate (CHAPS)) and 1\% DTT, mixed and placed on an orbital shaker for $2 \mathrm{~h}$ at $37^{\circ} \mathrm{C}$ to obtain complete protein solubilization. Samples were centrifuged $\left(14,000 \mathrm{rpm}, 60 \mathrm{~min}\right.$ at $\left.20^{\circ} \mathrm{C}\right)$ and the supernatants were recovered. The supernatant was desalted using PD spin trap columns (GE Healthcare Bio-sciences Corp, Piscataway, NJ, USA, Code no. 28-9180-04), stored at $-80{ }^{\circ} \mathrm{C}$ until use, and the protein concentration was determined by Bradford protein assay, using bovine serum albumin (BSA) as a standard.

\subsection{Two-Dimensional Electrophoresis (2DE) and Image Analysis}

Isoelectric focusing (IEF) was performed in $18 \mathrm{~cm}$ immobilized-pH-gradient (IPG) strips (GE Healthcare, Healthcare Bio-sciences Corp, Piscataway, NJ, USA) with a pH range of 4-7 L, rehydrated in a solution of $7 \mathrm{M}$ Urea, $2 \mathrm{M}$ thiourea, $4 \%$ CHAPS, $1 \%$ DTT, 2\% carrier ampholytes, and $1 X$ Protease inhibitor cocktail (Sigma-Aldrich Inc., St. Louis, MO, USA, Catalog no. P8340). About $100 \mu \mathrm{L}$ of total protein solution (equivalent to $500 \mu \mathrm{g}$ ) was loaded onto the focusing tray and left to be absorbed into the gel strip. The IPG strips were focused up to a total of $10 \mathrm{KVh}$ using a five step program (step $500 \mathrm{~V}$-for $3 \mathrm{~h}$, gradient-500 V for $5 \mathrm{~h}$, gradient $10 \mathrm{KV}$ for $8 \mathrm{~h}$ until $60 \mathrm{KVh}$ was reached, then finally $500 \mathrm{~V}$ for $10 \mathrm{~h}$ ) in an Ettan ${ }^{\mathrm{TM}}$ IPGphor ${ }^{\mathrm{TM}}$ isoelectric focusing system (Amersham Biosciences, Chicago, IL, USA). Focused strips were equilibrated by placing them in a solution of $6 \mathrm{M}$ urea, $0.05 \mathrm{M}$ Tris- $\mathrm{HCl}, \mathrm{pH} 8.8$, 20\% glycerol, 2\% Sodium dodecyl sulphate (SDS), and 2\% Dithiothreitol

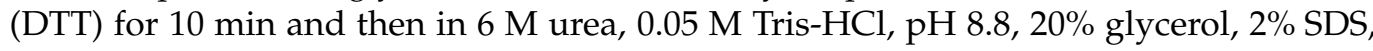
and $2.5 \%$ iodo-acetamide for a further $10 \mathrm{~min}$. For the second dimension SDS-PAGE, the IPG strips were loaded on top of $12.5 \%$ polyacrylamide gel in an Ettan ${ }^{\text {TM }}$ DALTsix Large 
vertical system (Amersham Biosciences, Chicago, IL, USA). Polyacrylamide gels were then electrophoresed at a constant voltage of $150 \mathrm{~V}$ for $60 \mathrm{~min}$ in Tris-glycine-SDS buffer, fixed in 40: 10\% v/v methanol: acetic acid (overnight) and stained with sensitive colloidal Coomassie blue G-250. Gels were destained with water, until the background was clear, and stored in 40: 10\% v/v methanol: acetic acid solution until further use. Protein patterns in the polyacrylamide gels were recorded as digitized images using a calibrated densitometric scanner (GE Healthcare, USA) and analyzed (normalization, spot matching, expression analyses, and statistics) using Image Master 2-D Platinum 6 image analysis software (GE Healthcare, USA). Spots on the gel were identified, and each spot was assigned a spot quantity (q); an approximate amount of protein based on relative spot size and intensity. Differential expression (DE) was measured as the relative ratio of $\mathrm{q}$ for the same spot between two comparative gels.

For proteomic analysis, spots were analyzed using Image Master 2-D Platinum image analysis software (GE Healthcare). One-way factor ANOVA $(p<0.05)$ was performed by keeping the values of the best-matched replicate gels from the two independent experiments. The normalized volume ( $\mathrm{vol} \%$ ) of each spot was automatically calculated by the Image analysis software.

\subsection{Mass Spectrometry and Protein Identification}

In-gel digestion and matrix-assisted laser desorption/ionization time of flight mass spectrometric (MALDI-TOF MS) analysis was performed with a MALDI-TOF/TOF mass spectrometer (Bruker Autoflex III smartbeam, Bruker Daltonics, Bremen, Germany), according to the method described by Shevchenko et al. (1996), with slight modifications. Two technical replicates (for each of the two biological replicates) representing each treatment were used, and the differentially expressed spots in the comparative gels were identified and manually excised from the gels. The excised gel pieces were then destained with $100 \mu \mathrm{L}$ of $50 \%$ acetonitrile $(\mathrm{ACN})$ in $25 \mathrm{mM}$ ammonium bicarbonate $\left(\mathrm{NH}_{4} \mathrm{HCO}_{3}\right)$ at least five times. Thereafter, the gel pieces were treated with $10 \mathrm{mM}$ DTT in $50 \mathrm{mM} \mathrm{NH}_{4} \mathrm{HCO}_{3}$ and incubated at $56^{\circ} \mathrm{C}$ for an hour. This was followed by treatment with $55 \mathrm{mM}$ iodo-acetamide in $50 \mathrm{mM} \mathrm{NH} \mathrm{HCO}_{3}$ for $45 \mathrm{~min}$ at room temperature in the dark $\left(25 \pm 2{ }^{\circ} \mathrm{C}\right)$, washed with $25 \mathrm{mM} \mathrm{NH}_{4} \mathrm{HCO}_{3}$ and $\mathrm{ACN}$, dried in Speed Vac, and rehydrated in $20 \mu \mathrm{L}$ of $25 \mathrm{mM}$ $\mathrm{NH}_{4} \mathrm{HCO}_{3}$ solution containing $12.5 \mathrm{ng} / \mu \mathrm{L}$ trypsin (sequencing grade, Promega, Madison, WI, USA). This mixture was incubated on ice for $10 \mathrm{~min}$ and digested at $37^{\circ} \mathrm{C}$ overnight. After digestion, the mixture was pulse spun for $10 \mathrm{~s}$ and the supernatant was collected in a fresh eppendorf tube. The gel pieces were re-extracted with $50 \mu \mathrm{L}$ of $0.5 \%$ trifluoroacetic acid (TFA) and ACN (1:1) for $15 \mathrm{~min}$, with frequent mixing. The supernatants were then pooled together and dried using Speed Vac and were reconstituted in $5 \mu \mathrm{L}$ of 1:1 ACN and $0.1 \%$ TFA. About $2 \mu \mathrm{L}$ of the above sample was mixed with $2 \mu \mathrm{L}$ of freshly prepared $\alpha$-cyano-4-hydroxycinnamic acid (CHCA) matrix in 50\% ACN and 0.1\% TFA (1:1), and $1 \mu \mathrm{L}$ was spotted onto the target plate.

Proteins were identified through database searches (PMF and MS/MS) using the MASCOT program (http: / /www.matrixscience.com, accessed on 31 October 2021) and employing BioTools software version 3.0 (Bruker Daltonics, San Jose, CA, USA). A homology search using mass values was performed with existing digests and sequence information from the NCBInr and Swiss-Prot database, by setting the taxonomic category to 'Other fungi', and setting the search parameters to fixed modification of carbamidomethyl (C), variable modification of oxidation (M), enzyme trypsin, peptide charge of $1^{+}$, and monoisotropic. According to the MASCOT probability analysis $(p<0.05)$, only significant 'hits' were accepted for protein identification. 


\section{Results and Discussion}

\subsection{Morphological Differences of Thermotolerant Isolates}

In the present investigation, two thermotolerant isolates of Trichoderma: T. longibrachiatum 673 (TaDOR673) and T. asperellum 7316 (TaDOR7316), which had previously been identified at IIOR, were used. These isolates were able to tolerate a heat shock of $52{ }^{\circ} \mathrm{C}$ for $4 \mathrm{~h}$ and were able to retain their morphological features after recovery from heat stress. The level of thermotolerance, however, was distinct between these isolates. The isolate TaDOR673 was highly tolerant to the heat shock condition tested, with a mean spore count $(\log$ c.f.u $/ \mathrm{mL})$ of 4.33 after the treatment, whereas TaDOR7316 had a mean spore count of 1.16. The two isolates exhibited distinct morphologies. TaDOR673 was a sparsely sporulating fungus with yellow pigmentation, whereas TaDOR7316 was a dense sporulating fungus (Figure 1). TaDOR673 was able to tolerate higher thermal stress, even at hyphal stage, when compared to TaDOR7316 [15].

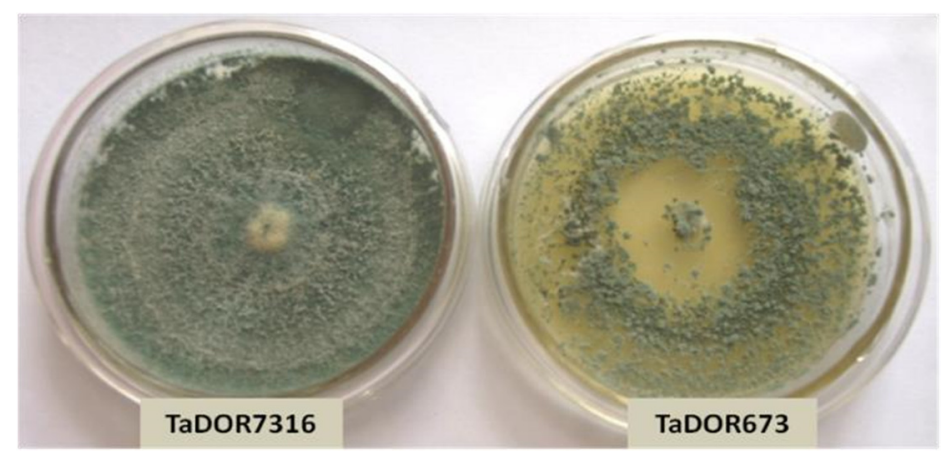

Figure 1. Morphology of thermotolerant isolates of Trichoderma.

Biochemical analysis revealed that both these isolates accumulate a higher concentration of trehalose, a known compatible solute, during heat shock [15]. We hypothesized that these morphological and physiological differences might contribute to their distinct levels of thermotolerance, and we used proteomic approaches to discern the changes associated with thermal stress in these two isolates of Trichoderma.

\subsection{Protein Profiling of Thermotolerant Isolates}

At temperatures higher than $48^{\circ} \mathrm{C}$, a significant reduction in protein abundance was observed (data not shown) in both the isolates, and, hence, an incubation temperature of $48^{\circ} \mathrm{C}$ was selected to perform the heat stress studies, and total protein was isolated from the strains exposed to $48^{\circ} \mathrm{C}$ after $1 \mathrm{~h}$ and $4 \mathrm{~h}$. We appreciate that some transiently upregulated proteins, either within one hour of exposure or those which were altered between $1 \mathrm{~h}$ and $4 \mathrm{~h}$, might have been missed from our analyses, as has been emphasized by Kusch et al. [40]

Using Coomassie brilliant blue staining, approximately 580 proteins were visualized in 2DE gels from each isolate (Figures 2 and 3). Two replicate gels were used to construct a representative master gel (RMG) for each sample. Protein spots with significant changes in expression-level were considered to be important for thermotolerance (Figures 4 and S1). A total of 32 protein spots were identified from both the isolates using MALDI-TOF-TOF (Tables 1 and 2). Among these proteins, proteins related to heat shock response were found to be commonly affected in both the isolates. As most of the protein hits were obtained with other fungi, a search against Trichoderma was also carried out using BLASTP to identify the homologous proteins (Tables S2 and S3). The presence of highly conserved domains was taken into consideration using NCBI's Conserved Domain Database (CDD). 

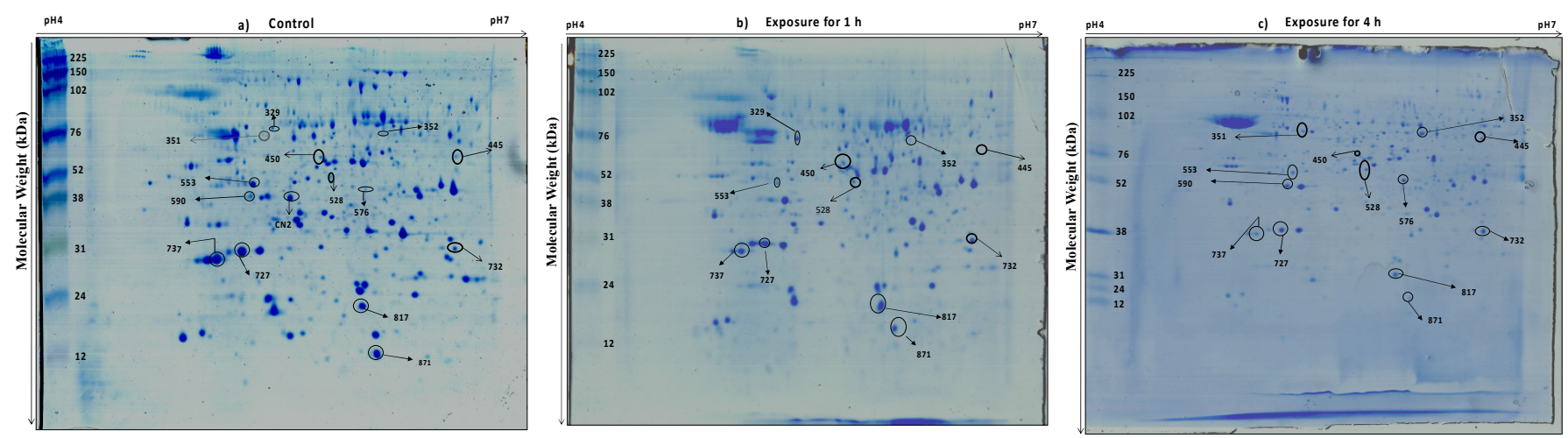

Figure 2. Two-dimensional gel image of the protein expression pattern in T. longibrachiatum 673, TaDOR673 under (a) control (grown at $28{ }^{\circ} \mathrm{C}$ ) and heat stress conditions at $48{ }^{\circ} \mathrm{C}$ for $1 \mathrm{~h}(\mathbf{b})$ and $4 \mathrm{~h}(\mathbf{c})$. The gels were obtained in duplicates; a representative of each duplicate is shown. Identified protein spots are numbered and listed in Table 1 . The $\mathrm{pH}$ gradient is marked above the gel, and the molecular mass protein standards (kDa) are indicated on the left of the gel.
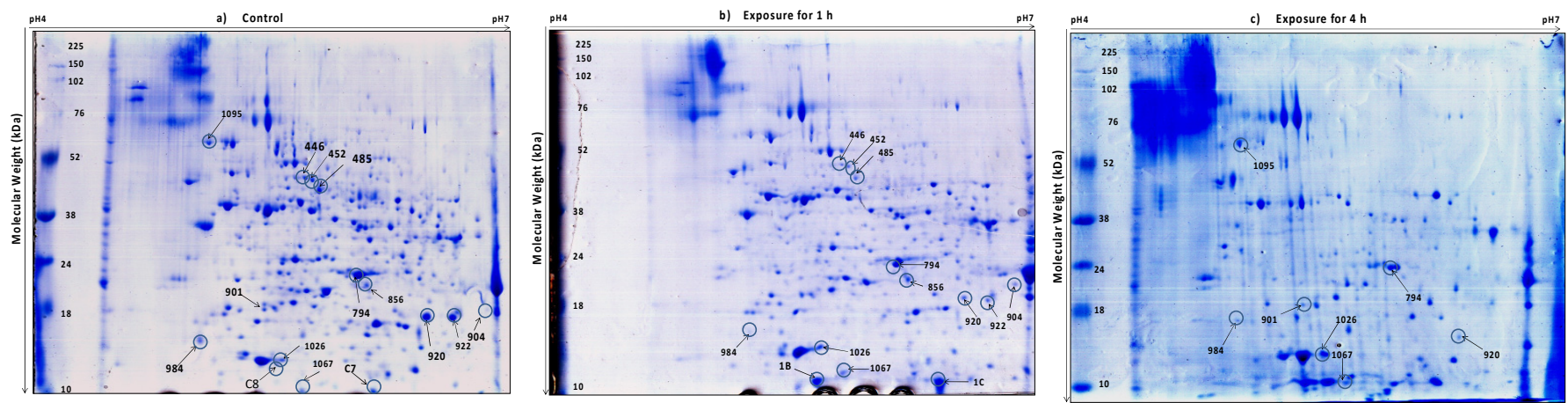

Figure 3. Two-dimensional gel image of the protein expression pattern in T. asperellum 7316, TaDOR7316 under (a) control (grown at $28{ }^{\circ} \mathrm{C}$ ) and heat stress conditions at $48{ }^{\circ} \mathrm{C}$ for $1 \mathrm{~h} \mathrm{(b)}$ and $4 \mathrm{~h}(\mathbf{c})$. The gels were obtained in duplicates; a representative of each duplicate is shown. Identified protein spots are numbered and listed in Table 2 . The $\mathrm{pH}$ gradient is marked above the gel, and the molecular mass protein standards (kDa) are indicated on the left of the gel.

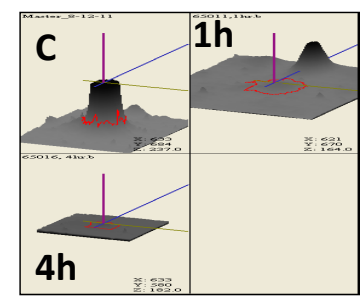

Spot: 871

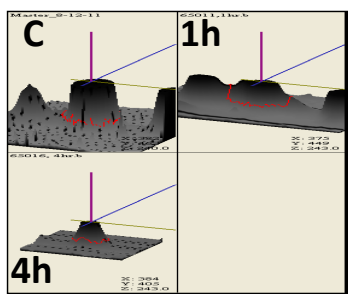

Spot: 727

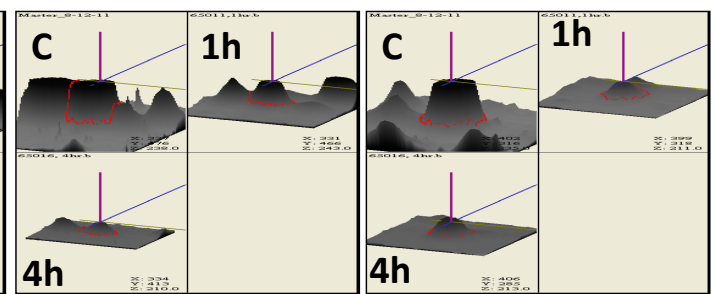

Spot: 737

Spot: 553

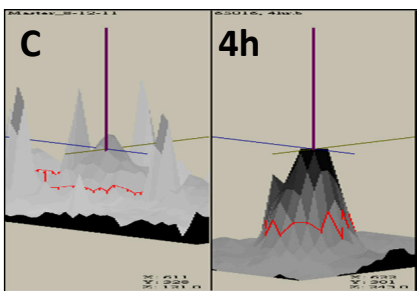

Spot: 576

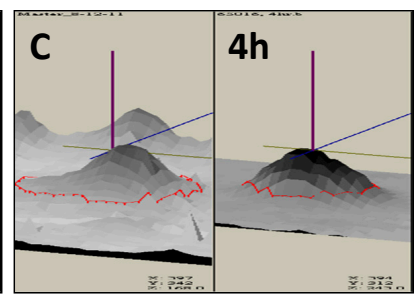

Spot: 590

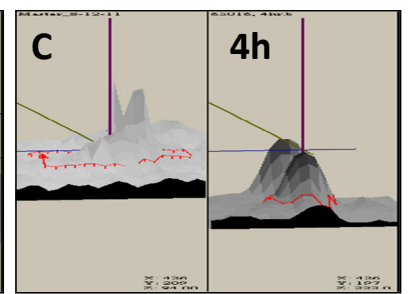

Spot: 351

Figure 4. 3D view of differential intensity levels of some of the protein spots identified in thermotolerant isolates of Trichoderma during the heat stress. Spot intensity was quantified by Image Master 2-D Platinum V6.0 image analysis software (GE Healthcare). The images show a peak for each protein spot, with a peak height that is proportional to the spot intensity. (C: control; $1 \mathrm{~h}$ : Heat stress at $48^{\circ} \mathrm{C}$ for $1 \mathrm{~h}$; $4 \mathrm{~h}$ : Heat stress at $48^{\circ} \mathrm{C}$ for $4 \mathrm{~h}$ ). 
Table 1. Differentially expressed proteins identified in T. longibrachiatum 673, TaDOR673 strain during heat stress through MALDI TOF-TOF.

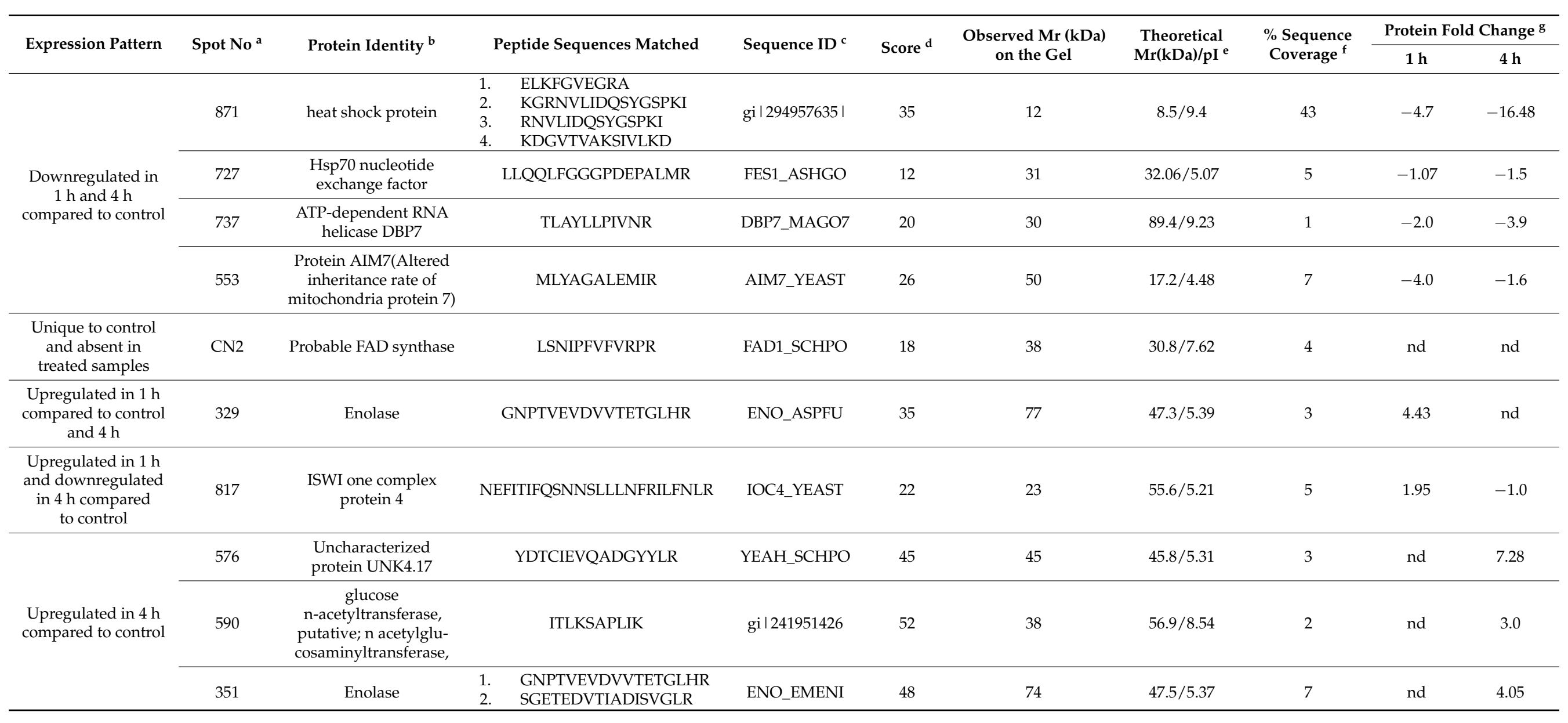


Table 1. Cont.

\begin{tabular}{|c|c|c|c|c|c|c|c|c|c|c|}
\hline \multirow{2}{*}{ Expression Pattern } & \multirow{2}{*}{ Spot No ${ }^{a}$} & \multirow{2}{*}{ Protein Identity ${ }^{b}$} & \multirow{2}{*}{ Peptide Sequences Matched } & \multirow{2}{*}{ Sequence ID ${ }^{c}$} & \multirow{2}{*}{ Score $^{d}$} & \multirow{2}{*}{$\begin{array}{c}\text { Observed Mr (kDa) } \\
\text { on the Gel }\end{array}$} & \multirow{2}{*}{$\begin{array}{c}\text { Theoretical } \\
\mathrm{Mr}(\mathrm{kDa}) / \mathrm{pI}^{\mathrm{e}}\end{array}$} & \multirow{2}{*}{$\begin{array}{c}\text { \% Sequence } \\
\text { Coverage }^{\mathrm{f}}\end{array}$} & \multicolumn{2}{|c|}{ Protein Fold Change } \\
\hline & & & & & & & & & $1 \mathrm{~h}$ & $4 \mathrm{~h}$ \\
\hline \multirow{5}{*}{$\begin{array}{l}\text { Upregulated in } 1 \mathrm{~h} \\
\text { and } 4 \mathrm{~h} \text { compared } \\
\text { to control }\end{array}$} & 450 & predicted protein & $\begin{array}{ll}\text { 1. } & \text { KGSVPQPK } \\
\text { 2. } & \\
& \text { GSVPQPKISNLSMPGVNK } \\
\text { 3. } & \text { ISNLSMPGVNK } \\
\text { 4. } & \text { KHNEDFEKK } \\
\text { 5. } & \text { HNEDFEK } \\
\end{array}$ & gi | 340521168 & 56 & 65 & $14.5 / 9.36$ & 21 & 2.51 & 2.0 \\
\hline & 352 & $\begin{array}{l}\text { Stress response } \\
\text { regulator protein } 1\end{array}$ & LTRPMVR & SRR1_LODEL & 19 & 76 & $40.1 / 5.85$ & 1 & 1.2 & 10.2 \\
\hline & 445 & $\begin{array}{l}\text { Heat shock factor } \\
\text { protein }\end{array}$ & SGSIQSSSDDK & HSF_YEAST & 25 & 60 & $93.2 / 5.2$ & 1 & 1.3 & 1.5 \\
\hline & 528 & Enolase & $\begin{array}{ll}\text { 1. } & \text { GNPTVEVDVVTETGLHR } \\
2 . & \text { SGETEDVTIADISVGLR } \\
\end{array}$ & ENO_EMENI & 48 & 55 & $47.5 / 5.37$ & 7 & 1.47 & 2.2 \\
\hline & 732 & $\begin{array}{c}\text { GDP-Man:Man (3) } \\
\text { GlcNAc (2)-PP-Dol } \\
\text { alpha-1,2- } \\
\text { mannosyltransferase }\end{array}$ & LKISPNDCENGDGFLNEMSR & ALG11_CANAL & 31 & 31 & $71.2 / 8.68$ & 3 & 2.43 & 3.42 \\
\hline
\end{tabular}

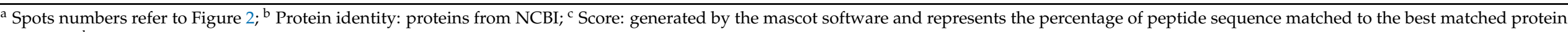

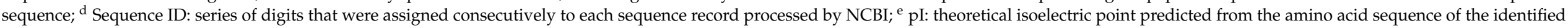

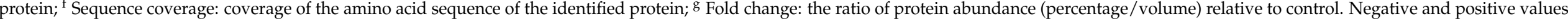
represent reduced and increased expression of proteins, respectively; nd: not detected. 
Table 2. Differentially expressed proteins identified in T. asperellum 7316, TaDOR7316 proteins during heat stress through MALDI TOF-TOF.

\begin{tabular}{|c|c|c|c|c|c|c|c|c|c|c|}
\hline \multirow[b]{2}{*}{ Expression Pattern } & \multirow{2}{*}{$\begin{array}{l}\text { Spot } \\
\text { No }^{a}\end{array}$} & \multirow{2}{*}{ Protein Identity ${ }^{b}$} & \multirow{2}{*}{ Peptide Sequences Matched } & \multirow{2}{*}{ Sequence ID ${ }^{c}$} & \multirow{2}{*}{ Score $^{\mathrm{d}}$} & \multirow{2}{*}{$\begin{array}{c}\text { Observed } \\
\text { Mr (kDa) on } \\
\text { the Gel }\end{array}$} & \multirow{2}{*}{$\begin{array}{l}\text { Theoretical } \\
\mathrm{Mr}(\mathrm{kDa}) / \mathrm{pI}^{\mathrm{e}}\end{array}$} & \multirow{2}{*}{$\begin{array}{l}\% \text { Sequence } \\
\text { Coverage }^{f}\end{array}$} & \multicolumn{2}{|c|}{ Protein Fold Change } \\
\hline & & & & & & & & & $1 \mathrm{~h}$ & $4 \mathrm{~h}$ \\
\hline \multirow[t]{2}{*}{$\begin{array}{l}\text { Unique to } 1 \mathrm{~h} \\
\text { treated samples }\end{array}$} & $1 \mathrm{~B}$ & $\begin{array}{l}\text { Conserved oligomeric } \\
\text { Golgi complex } \\
\text { subunit } 6\end{array}$ & $\begin{array}{l}\text { ALSLPIATNIETFGR } \\
\text { HRPHYLNSVLATFVGSR }\end{array}$ & COG6_PICGU & 68 & 11 & $85.5 / 5.05$ & 4 & - & nd \\
\hline & $1 \mathrm{C}$ & $\begin{array}{l}\text { Hypothetical protein } \\
\text { TRIATDRAFT_306007 }\end{array}$ & GPHLGQAFLPIFDVR & gi | 358398918 & 56 & 10 & $20.6 / 5.61$ & 8 & - & nd \\
\hline \multirow{3}{*}{$\begin{array}{l}\text { Downregulated in } \\
1 \mathrm{~h} \text { compared } \\
\text { to control }\end{array}$} & 485 & $\begin{array}{l}\text { UDP-galactopyranose } \\
\text { mutase }\end{array}$ & $\begin{array}{l}\text { YFDDCIDEALPNEDDWFTHQR } \\
\text { CWLYFPEDDCPFYR }\end{array}$ & gi | 406861020 & 104 & 41 & $58.9 / 5.64$ & 6 & -2.9 & nd \\
\hline & 922 & $\begin{array}{l}\text { Lysophospholi-pase } \\
\text { NTE1 }\end{array}$ & AGNPVSSLVNILNLFTSANDNVTSPSR & NTE1_CANGA & 19 & 17 & $193.5 / 8.29$ & 1 & -4.3 & nd \\
\hline & 452 & GTP-cyclo-hydrolase II & $\begin{array}{ll}\text { 1. } & \text { FAVEPTWYLPGVAER } \\
\text { 2. } & \text { SLFEHTGGSYPELITR } \\
\end{array}$ & gi | 453083792 & 93 & 45 & $59.1 / 6.23$ & 5 & -2.3 & nd \\
\hline $\begin{array}{l}\text { Upregulated in } 1 \mathrm{~h} \\
\text { and } 4 \mathrm{~h} \text { compared } \\
\text { to control }\end{array}$ & 1026 & $\begin{array}{l}\text { tRNA N6-adenosine } \\
\text { threonylcarbamoyl- } \\
\text { transferase }\end{array}$ & MGKPLIALGLEGSANK & KAE1_SCHPO & 26 & 12 & $38.06 / 7.55$ & 4 & 2.2 & 4.2 \\
\hline $\begin{array}{l}\text { Upregulated in } 4 \mathrm{~h} \\
\text { compared to control } \\
\text { and } 1 \mathrm{~h}\end{array}$ & 1095 & Kexin & STTTTSSTTTATTTSGGEGDQK & KEX2_CANAW & 25 & 60 & $105.4 / 4.86$ & 2 & nd & 2.1 \\
\hline \multirow{2}{*}{$\begin{array}{l}\text { Unique to control } \\
\text { and absent in } \\
\text { treated samples }\end{array}$} & $\mathrm{C} 7$ & $\begin{array}{l}\text { Vacuolar protein } \\
\text { sorting/targeting } \\
\text { protein } 10\end{array}$ & RIHLHSVTELNNVGRKIPGNTCK & VPS10_SORMK & 46 & 10 & $173.2 / 5.63$ & 1 & nd & nd \\
\hline & C8 & $\begin{array}{l}\text { Serine/threonine- } \\
\text { protein phosphatase } 2 \mathrm{~B} \\
\text { catalytic subunit } \mathrm{A} 1\end{array}$ & $\begin{array}{l}\text { 1. TPISSAIASGSPGSPGTPTSPSIGGP- } \\
\text { PLTAWRPGHGR }\end{array}$ & PP2B1_CRYNH & 20 & 12 & $72.19 / 5.11$ & 5 & nd & nd \\
\hline $\begin{array}{l}\text { Downregulated in } \\
4 \mathrm{~h} \text { compared } \\
\text { to control }\end{array}$ & 901 & $\begin{array}{l}\text { Phosphatidylgly- } \\
\text { cerophosphatase GEP4 }\end{array}$ & MNISGTLNTLR & GEP4_YEAST & 32 & 18 & $21.1 / 8.87$ & 5 & nd & -1.14 \\
\hline \multirow{2}{*}{$\begin{array}{l}\text { Upregulated in } 1 \mathrm{~h} \\
\text { compared to control }\end{array}$} & 904 & $\begin{array}{l}\text { Probable tripeptidyl- } \\
\text { peptidase SED4 }\end{array}$ & ELYKMGNTFATKDPR & SED4_TRIVH & 37 & 17 & $65.6 / 5.87$ & 2 & 2.4 & nd \\
\hline & 856 & $\begin{array}{l}\text { autophagy-related } \\
\text { protein } 28\end{array}$ & DGLDEDPLSPAGSISKLKPR & gi | 429854636 & 67 & 20 & $65.7 / 5.39$ & 3 & 2.7 & nd \\
\hline
\end{tabular}


Table 2. Cont.

\begin{tabular}{|c|c|c|c|c|c|c|c|c|c|c|c|}
\hline \multirow{2}{*}{ Expression Pattern } & \multirow{2}{*}{$\begin{array}{l}\text { Spot } \\
\text { No }^{a}\end{array}$} & \multirow{2}{*}{ Protein Identity $^{b}$} & & \multirow{2}{*}{ Peptide Sequences Matched } & \multirow{2}{*}{ Sequence ID ${ }^{c}$} & \multirow{2}{*}{ Score ${ }^{d}$} & \multirow{2}{*}{$\begin{array}{l}\text { Observed } \\
\text { Mr (kDa) on } \\
\text { the Gel }\end{array}$} & \multirow{2}{*}{$\begin{array}{c}\text { Theoretical } \\
\mathrm{Mr}(\mathbf{k D a}) / \mathrm{pI}^{\mathrm{e}}\end{array}$} & \multirow{2}{*}{$\begin{array}{c}\% \text { Sequence } \\
\text { Coverage } f\end{array}$} & \multicolumn{2}{|c|}{ Protein Fold Change } \\
\hline & & & & & & & & & & $1 \mathrm{~h}$ & $4 \mathrm{~h}$ \\
\hline \multirow{3}{*}{$\begin{array}{l}\text { Downregulated in } \\
1 \mathrm{~h} \text { and } 4 \mathrm{~h} \\
\text { compared to control }\end{array}$} & 920 & $\begin{array}{l}\text { Subtilisin-like } \\
\text { protease } 8\end{array}$ & 2 & $\begin{array}{l}\text { YIYAAQGGEGVDAYVIDTGT- } \\
\text { NIEHVDFEGR } \\
\text { AYFSNYGK }\end{array}$ & SUB8_ARTOC & 183 & 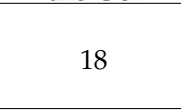 & $52.6 / 5.90$ & 7 & -4.18 & -7.8 \\
\hline & 984 & $\begin{array}{c}\text { Putative } \\
\text { ATP-dependent RNA } \\
\text { helicase C550.03c }\end{array}$ & \multicolumn{2}{|c|}{ HMIMGPSSKLISQFRLTYNMILNLLR } & SKI2_SCHPO & 37 & 15 & $138.6 / 6.30$ & 2 & -6.2 & -3.7 \\
\hline & 794 & $\begin{array}{l}\text { Fructose-bisphosphate } \\
\text { aldolase, class II }\end{array}$ & $2+2+3$ & $\begin{array}{l}\text { EKKFAIPAI- } \\
\text { NVTSSSTVVASLEAAR } \\
\text { VNMDTDMQFAYMAGIR }\end{array}$ & gi | 346326492 & 81 & 21 & $39.1 / 5.71$ & 11 & -2.1 & -3.0 \\
\hline
\end{tabular}

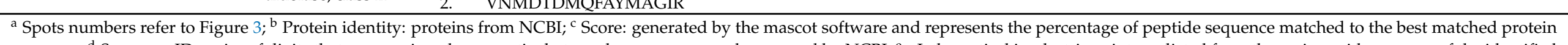

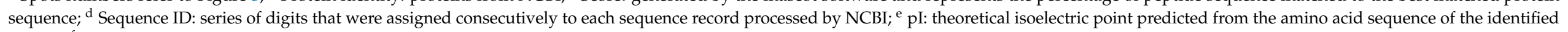

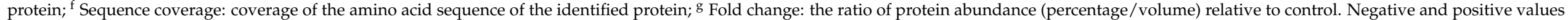
represent reduced and increased expression of proteins respectively; nd: not detected. 


\subsection{Differentially Expressed Proteins Common in the Two Trichoderma Strains}

\subsubsection{Proteins of Cell Wall Remodeling}

There were differentially expressed proteins that were common between the two isolates tested (Tables 1, 2, S2 and S3). These proteins belonged to different cellular processes and are briefly discussed here.

The cell wall plays a crucial role in sensing and adapting to adverse stress conditions, and earlier reports have shown that cell wall polysaccharides and lipid modifications contribute significantly to the induced heat and salt tolerance [24]. The composition of Trichoderma cell wall carbohydrates vary among species but are mainly composed of glucose, $N$-acetyl-glucosamine, $N$-acetylgalactosamine, galactose, and mannose [54,55]. In TaDOR673, glucose N-acetyltransferase (Spot 590), which is involved in chitin synthesis, was found to be absent after $1 \mathrm{~h}$ exposure, but was upregulated three-fold after $4 \mathrm{~h}$, indicating the activation of chitin biosynthesis during prolonged exposure to higher temperatures. Chitin constitutes 10-30\% of fungal cell walls [56] and is actively synthesized during stress conditions $[25,57]$. It has been hypothesized that N-acetylglucosamine (GlcNAc), a major component of fungal cell wall chitin, might be a conserved cue to morphogenesis [58] and be a mediator of cell signaling [27] during heat stress conditions.

Other cell wall proteins, such as $\alpha-1,2-$ mannosyltransferase (Spot 732), involved in cell wall biosynthesis were also found to be upregulated two-fold and three-fold during $1 \mathrm{~h}$ and $4 \mathrm{~h}$ exposure, respectively; indicating that $\mathrm{N}$-glycosylation, a major protein modification known to occur in different cells [59], perhaps plays a crucial role in response to high-temperature stress in this organism. However, in the moderately thermotolerant Trichoderma strain, TaDOR7316, a reduced expression of some of the proteins involved in cell wall remodeling was observed. The enzyme UDP-galactopyranose mutase (Spot 485), which is involved in the synthesis of the cell wall component galactofuranose [60], was downregulated three-fold after $1 \mathrm{~h}$ exposure and was below the limit of detection at $4 \mathrm{~h}$. Phospholipase B (PLB) protein (Spot 922), which is important for the turnover of phosphatidylcholine in cell membrane [61], was also repressed ( 4-fold) during hightemperature stress. The physiological functions of fungal PLB are largely unknown, but recently the role of a PLB homolog was identified as a mediator of osmotic stress response in fission yeast [28]. The functional role of these proteins in imparting stress tolerance to the TaDOR7316 strain needs to be empirically determined.

In TaDOR7316, the membranes of cellular organelles were also impacted by hightemperature stress. Phosphatidylglycerophosphatase GEP4 (Spot 901), which is involved in cardiolipin biosynthesis, was not detected during $1 \mathrm{~h}$ exposure to heat stress, but was expressed at a low level (compared to control) during prolonged thermal stress. Cardiolipin levels seem to be important for osmoadaptation [62] and in the cross-talk between mitochondria and vacuole [26]. Thus, in TaDOR7316, mitochondrial cell membrane signaling could be involved in the activation of other stress response pathways, which help it to ensure protection against thermal stress.

\subsubsection{Proteins of Carbohydrate Metabolism}

The proteins of glycolysis and gluconeogenesis pathways are highly influenced during different stress conditions, and the choice of the mechanism chosen by the organism to combat thermal stress mainly depends on the cytosol composition of the organism [63]. This probably explains why different organisms choose either gluconeogenesis $[34,40,64]$ or glucose catabolism $[42,65]$ to maintain cellular homeostasis during different stress conditions.

In TaDOR673, three isoforms of enolase (Spot 329, 528, and 351) were upregulated two- and four-fold during $1 \mathrm{~h}$ and $4 \mathrm{~h}$ exposure to heat stress (Table 1); and in agreement with our results, similar observations were made in several other fungi $[35,57]$. With enolase being an important enzyme in carbohydrate metabolism and a major cell-envelope associated protein of $T$. reesei [66], we speculate that it could be involved in combating the heat stress conditions. 
In contrast to the above, in TaDOR7316, the enzyme fructose 1,6 bisphosphate aldolase (Spot 794), which catalyzes a reversible reaction of conversion of fructose 1,6-bisphosphate to dihydroxyacetone phosphate and glyceraldehyde 3-phosphate, was downregulated by two-fold in $1 \mathrm{~h}$ and three-fold in $4 \mathrm{~h}$ treated samples. Thus, we hypothesize that this downregulation might lead to decreased use of the TCA cycle and increased glycerol biosynthesis, as observed in osmo-regulated cells of Aspergillus nidulans [34]. This in turn would act as an osmoprotectant, protecting cells against dehydration or temperature stress [63].

\subsubsection{Proteins of the Heat Shock Response (HSR) Pathway}

The role of Trichoderma-derived heat shock proteins in stress tolerance has been well documented [22], and it is commonly observed that under various stress conditions, the heat shock proteins Hsp70 and Hsp60 are expressed in coordination to ensure proper protein folding and maturation of nascent polypeptides [34,35].

Interestingly, in TaDOR673, Hsp70 nucleotide exchange factor Fes1 (Spot 727) and mitochondrial Hsp60 (Spot 871) were downregulated by 1.5-fold and 1.6-fold, respectively, during prolonged exposures to heat stress. These results were in agreement with earlier reports, where the authors mentioned a reduced expression of Hsp60 in fungal cells exposed to $\mathrm{pH}$ stress [42]. In normal cells, Fes1 specifically targets misfolded proteins recognized by Hsp70 in the ubiquitin/proteasome system (UPS), and cells lacking Fes1 are hypersensitive to induced protein misfolding and display a strong and constitutive heat shock response, mediated by heat shock transcription factor, hsf 1 [32,33]. Thus, induced expression of heat shock transcription factor (Spot 445 ) in TaDOR673 ( 1.5 fold) probably indicates the activation of a constitutive heat shock response in the absence of Fes1, and we hypothesize that during high-temperature stress, Hsp70 might use other dominant nucleotide exchange factors of the Hsp110 class to maintain the aggregation-prone proteins soluble in the cell, rather than targeting them to UPS for protein degradation. Moreover, it could also be possible that Hsf1 that was upregulated at higher temperatures and might be involved in the diverse cellular processes, such as cell wall remodeling, carbohydrate metabolism, energy generation, etc., during heat stress, as suggested previously $[36,67]$.

It was interesting to observe that the small heat shock protein (sHsp), Hsp23 (Spot 1C), was induced during the initial hours of higher temperature in TaDOR7316, unlike in TaDOR673. Overexpression of Hsp23 correlated with the increased thermotolerance in T. harzianum reported previously [20]. In our study, overexpression of Hsp23 was confined to only during the early hours of heat stress; we speculate that there could be an increased accumulation of denatured proteins in TaDOR7316, compared to TaDOR673, during high-temperature stress. These sHsps, which are crucial for preventing stress-induced aggregation of partially denatured proteins, could rescue this organism from heat stress and aid in the restoration of the native conformations of denatured proteins when favorable conditions are restored. However, further studies are necessary to understand the role of these heat shock proteins in high-temperature stress in these isolates.

\subsubsection{Proteins of the Cell Signaling Pathway}

A hypothetical protein (Spot 352) in TaDOR673, which possessed a conserved domain for a stress response regulator, was identified as an over-expressed protein at elevated temperatures (from 1 -fold in $1 \mathrm{~h}$ to 10 -fold in $4 \mathrm{~h}$ ). This hypothetical protein could be the major stress signaling molecule of heat stress in TaDOR673, which in turn helps in the activation of other stress response genes. Trichoderma is known to use the Hog1mediated mitogen-activated protein kinase (MAPK) pathway in response to stress [23] in a two-component phosphor-relay system, where a phosphoryl group is transferred from a membrane bound sensor histidine kinase to an internal receiver domain. The phosphoryl group is then shuttled through a histidine phosphor-transfer protein to a terminal response regulator (RR). When stress signals such as oxidants, high salt, etc. are detected by cells, the RR protein is dephosphorylated and is able to activate the downstream MAPK pathway 
to render cells adapted to the stress [29,30]. In addition, homologs of yeast RR have been identified in other fungi and were found to be involved in stress adaptation [68]. We therefore speculate that this hypothetical protein in TaDOR673 could be involved in the activation of the MAPK pathway in response to high temperature.

However, in TaDOR7316, we observed the differential expression of calcineurin, which is a serine/threonine protein phosphatase. Calcineurin is activated by $\mathrm{Ca}^{2+}$-calmodulin, by binding to the catalytic subunit, CnaA [69]. Interestingly in TaDOR7316 the catalytic subunit of calcineurin, which had a PP2B conserved domain (Spot C8) was not detected during high-temperature stress. However, further experiments are needed to draw conclusions about the significance of these observations for high-temperature tolerance.

\subsection{5. mRNA Stability}

Other proteins that were common in the thermotolerant isolates were the RNA helicases. Two hypothetical proteins with conserved domains for helicases were found to be significantly downregulated in TaDOR673 (Spot 737) and TaDOR7316 (Spot 984), respectively. As is evident from Tables 1 and 2, the expression of RNA helicases was comparatively lower in TaDOR7316 ( 4-6-fold) than in TaDOR673 ( 3-fold). The cellular requirement for increased RNA helicase abundance is generally associated with the alteration of the stability of the RNA secondary structure in response to stress [70,71], and our results corroborate other studies, which showed that a mutation in helicase function enhanced cellular tolerance to oxidative stress [72].

In addition to maintaining the mRNA structure, RNA helicases are also implicated in specialized processes, including cell growth, differentiation, development, small RNA (sRNA) metabolism, and response to abiotic stress [73-76]. In this context, it is interesting that downregulation of RNA helicase expression in response to stress has rarely been reported [74]. The downregulation of RNA helicases in our study points to a possible mechanism involved in induced stress tolerance when RNA helicases are either deleted/inactivated.

In spite of the reduced levels of RNA helicases, the TaDOR7316 strain seemed to protect its mRNA pool by increased expression ( $~ 8$ fold) of other mRNA protecting enzymes (Spot 1067). This hypothetical protein probably identifies and hydrolyzes the aberrantly capped mRNA produced during heat stress, in a manner similar to that observed in yeast [77].

\subsection{Proteins Unique to TaDOR673}

Apart from the major stress response pathways, the proteins involved in actin depolymerization (Spot 553) and the proteins of sulfur metabolism (Spot CN2) were downregulated during prolonged exposures to heat stress. As listed in Table 1, high-temperature stress is probably ineffective on the actin cytoskeleton during $1 \mathrm{~h}$ exposure, but seemed to slowly affect actin depolymerization at $4 \mathrm{~h}$. Similar observations were made by Malerba et al. [78] in yeast cells exposed to mild, moderate, and high heat stress. We hypothesize that $48^{\circ} \mathrm{C}$ is perhaps a moderate stress to TaDOR673 and, therefore, it probably did not undergo major cytoskeleton modifications at this level of heat stress.

A predicted protein with a conserved domain of PWWP (Spot 817) was upregulated in $1 \mathrm{~h}$ ( 2-fold) but downregulated 1-fold after $4 \mathrm{~h}$ of heat stress. PWWP domain containing proteins possess DNA or histone binding activity [79], and to our knowledge this is the first report to describe the role of a chromatin remodeling protein in Trichoderma under high-temperature stress. Chromatin remodeling is known to be essential for ensuring the stress-inducible binding of transcription factors, viz., Hsf1 to the majority of its targets [80], and, thus, could act as a major regulator of the stress induced response of the fungus. This would be a good candidate gene for detailed analysis, to understand the mechanisms of heat stress tolerance.

In addition to these changes, increased expression ( 7 fold) of oxidoreductases (Spot 576) was observed during prolonged heat stress conditions. As these enzymes 
mediate essential redox reactions in cells, they may be important in response to various stresses [64,81]. A hypothetical protein (Spot 450) was also identified as deregulated during heat stress, but its probable function could not be deciphered, due to lack of conserved domain information (Table S2).

\subsection{Proteins Unique to TaDOR7316}

\subsubsection{Unfolded Protein Response (UPR) and Protein Turnover}

Among fungi, Trichoderma is predicted to contain a wealth of proteases (as predicted with the use of the peptidase database MEROPS http://merops.sanger.ac.uk, Rawlings et al. [50]). Of these the dominant groups include aspartyl proteases, serine proteases, subtilisin-like proteases, dipeptidyl, and tripeptidyl peptidases [82]. In the present study, two proteins belonging to the protease S8 and S53 family were upregulated at higher temperature (Spot 1095; homologous to T. virens subtilisin-like protease, EHK25893.1, and Spot 904; homologous to T. reesei tripeptidyl-peptidase 1 precursor, ETR98149.1). These proteins were upregulated $\sim 2$-fold, both at $4 \mathrm{~h}$ and $1 \mathrm{~h}$ of heat treatments. Interestingly, a hypothetical protein (Spot 920), homologous to T. atroviride vacuolar serine protease, ABG57252.1 was found to be downregulated during heat stress. Therefore, in TaDOR7316, upregulation of these different proteases of the UPR pathway could be essential to the targeting of the misfolded or denatured proteins for degradation. Moreover, this process helps in, both the recycling of amino acids, as well as clearing the cellular matrix $[18,83]$.

Based on our results, we speculate that under high-temperature stress, misfolded proteins activate different enzymes of the unfolded protein response (UPR) pathway in the endoplasmic reticulum (ER), and in turn the UPR being an ER-to-nucleus signal transduction pathway might regulate a wide variety of target genes, to maintain cellular homeostasis, as reported earlier [84,85].

\subsubsection{Vacuole Biogenesis and Autophagy}

We observed an increased expression of an autophagy protein, Apg6 (Spot 856), and two hypothetical proteins (Spot 1B and Spot 1026) with conserved oligomeric-Golgi domains (COG) during the stress conditions (Table 2). It was observed that under stress, when the ER-associated degradation (ERAD) pathway for misfolded proteins is saturable, cellular homeostasis is maintained by the UPR pathway, which transports the excess substrate (misfolded proteins) to the vacuole for protein turnover [85]. Studies have shown that the endocytic pathways, proteosome pathways, and regulation of autophagy are induced during heat stress in filamentous biocontrol fungi [17]. COG complex, which helps in the formation of double-membrane sequestering vesicles during autophagy [86], is principally important for retrograde trafficking within the Golgi complex and possibly for ER transport to Golgi and endosome transport to the Golgi complex [87-91].

Thus, we hypothesized that under heat stress, TaDOR7316 probably tries to maintain the native conformation of proteins during the initial hours of exposure, by inducing the expression of heat shock proteins (Hsp23 as mentioned in above sections), but during prolonged exposures to heat stress, it probably maintains cellular homeostasis by deploying the UPR pathway to transport the increased levels of denatured/misfolded proteins to vacuoles for degradation.

Several vacuolar protein sorting complexes exist in cells, to help the efficient retrograde transport of proteins, from endosome-to-Golgi complex. Their roles in stress resistance, host cell interactions, and virulence have also been well documented [41]. In the present study, the expression of a vacuolar sorting protein with a conserved domain of VPS10 was identified in unstressed samples but was not detected under stress conditions in TaDOR7316 (Spot C7). The VPS10 encodes a Carboxypeptidase Y (CPY) sorting receptor that executes multiple rounds of sorting, by cycling between the late Golgi and a prevacuolar endosome-like compartment. Studies have shown that mutations in VPS10 resulted in selective mis-sorting and secretion of CPY, but had no impact on the delivery of other vacuolar proteins [92]. Thus, we speculate that in TaDOR7316, in spite of the absence 
of certain vacuolar sorting signal molecules, the fate of most of the misfolded proteins might be taken care of by the proteins of the UPR pathway, and that in turn might trigger vacuole biogenesis and autophagy, to maintain protein turnover and cellular homeostasis.

\subsection{Other Proteins}

A protein involved in DNA replication (spot 446, homologous to T. reesei QM6a DNA polymerase epsilon, XP_006964819.1) was downregulated by two-fold in $1 \mathrm{~h}$ and completely repressed with $4 \mathrm{~h}$ exposure to heat stress in TaDOR7316. Although little is known about its effects on DNA integrity and the DNA replication process, it has been shown that in yeast the absence of topoisomerase activities did not prevent the induction of either heat or radiation resistance. However, if both topoisomerase I and II activities were absent, the sensitivity of yeast to becoming thermally tolerant was markedly increased [93].

We identified a hypothetical protein (Spot 452) homologous to GTP cyclohydrolase of T. reesei QM6a, whose expression was repressed by two-fold during $1 \mathrm{~h}$ and was below the detection limits at $4 \mathrm{~h}$ of heat stress. GTP cyclohydrolase is involved in riboflavin biosynthesis, and in turn, riboflavin protects cells from stress injuries [94,95]. Elevated riboflavin is required for post-photoinductive events in sporulation of a Trichoderma auxotroph [96] and downregulation of this enzyme probably explains the reduced sporulation observed in TaDOR7316 during the heat stress. Similar results were also observed in A. nidulans and Ashbya gossypii exposed to oxidative stress agents [81,97]. However, further studies are required to understand the exact role of these proteins in heat stress tolerance.

We also appreciate the fact that the differential protein expression in these two different strains of Trichoderma during heat stress could also be associated with the differences in biology of these two strains. Different species of Trichoderma are known to promote the biotic and abiotic stress tolerance of various crops using difference mechanisms, such as production of heat shock proteins, increased reactive oxygen species (ROS) production, and auxin signaling [98]. To the best of our knowledge, our study is the first to compare the biological responses of two different strains of Trichoderma in response to thermal stress. However, to gain further insights into the mechanism of thermotolerance in the two strains used in this study, we also carried out a microarray analysis to profile the altered expression in transcripts due to higher temperature (Poosapati et al., manuscript under preparation). By comparing the proteomic and transcriptome data, we would like to establish the correlation between the transcript and protein levels.

\section{Conclusions}

In our study, we compared the proteins profiles of two different thermotolerant isolates of Trichoderma under heat stress. These isolates differed in their level of thermotolerance, and, as hypothesized, we identified some putative heat stress responsive proteins that are probably responsible for the thermotolerance levels of TaDOR673 and TaDOR7316. We propose that in TaDOR673, under heat stress, the organism undergoes cell wall changes and metabolic changes, such as increased chitin production and increased enolase and trehalose biosynthesis. In addition, stress signals could be sensed by putative cell membrane sensors, which in turn transfer the signals to response regulators (RR) and activate the MAPK signaling pathway. The HSR pathway also seems to play a crucial role in the thermotolerance of TaDOR673. Based on proteomic changes, we hypothesize that Hsf1 might be involved in cell wall remodeling, to combat the heat stress in TaDOR673 strain. However, in the moderately thermotolerant isolate, TaDOR7316, heat stress probably resulted in increased accumulation of misfolded proteins, and in order to protect the cell from toxicity, misfolded proteins were targeted for degradation through UPR and autophagy. Moreover, sHsps, like Hsp23, were found to be a part of early stress responses in TaDOR7316. Thus, we observed that the superior thermotolerant isolate, TaDOR673, was able to manage the levels of heat stress through the activation of stress signaling and heat shock response pathways, whereas the moderately thermotolerant isolate, TaDOR7316 experienced severe stress during prolonged exposures to higher temperatures, and the strain could circumvent the heat 
stress by getting rid of toxic proteins, to maintain cellular homeostasis. Further studies are required to empirically establish the functional role of the differentially expressed proteins in these two strains during exposure to higher temperatures. Our study, thus, provides some important clues for future research in the area of Trichoderma proteomics.

Supplementary Materials: The following are available online at https:/ /www.mdpi.com/article/10 .3390/jof7121002/s1, Figure S1: 3D view of differential intensity levels of protein spots identified in thermotolerant isolates of Trichoderma during the heat stress. Spot intensity was quantified by Image Master 2-D Platinum V6.0 image analysis software (GE Healthcare). The images show a peak for each protein spot, with a peak height that is proportional to the spot intensity. (C: control; $1 \mathrm{~h}$ : Heat stress at $48{ }^{\circ} \mathrm{C}$ for $1 \mathrm{~h} ; 4 \mathrm{~h}$ : Heat stress at $48^{\circ} \mathrm{C}$ for $4 \mathrm{~h}$ ). Table S1: List of accession numbers of thermotolerant Trichoderma isolates. Table S2: BLASTP and CDD (Conserved domain) analyses of protein identified during heat stress in T. longibrachiatum 673, TaDOR673. Table S3: BLASTP and CDD (Conserved domain) analyses of protein identified during heat stress in T. asperellum 7316, TaDOR7316.

Author Contributions: D.K.V., P.D.R. and S.P. conceived and designed the study; S.P. and M.K. performed the experiments and analyzed the data; S.P., D.K.V. and P.D.R. wrote the paper. All authors have read and agreed to the published version of the manuscript.

Funding: This research was funded by National Agricultural Innovation Program (Project no.C2082), ICAR, New Delhi, India.

Institutional Review Board Statement: Not applicable.

Informed Consent Statement: Not applicable.

Data Availability Statement: The accession numbers of thermotolerant isolates of Trichoderma are available in NCBI, https: / / www.ncbi.nlm.nih.gov /, accessed on 31 October 2021.

Acknowledgments: The authors gratefully acknowledge the facilities extended by the Director, Indian Institute of Oilseeds Research (formerly Directorate of Oilseeds Research), Rajendranagar, Hyderabad, India for carrying out this research. The authors would also like to thank Lekha Dinesh Kumar, CCMB, Habsiguda, Velu Mani Selvaraj and Anil Kumar, Research Scholars at IIOR, Hyderabad for their technical support.

Conflicts of Interest: The authors declare no conflict of interest.

\section{References}

1. Verma, M.; Brar, S.; Tyagi, R.; Surampalli, R.; Valero, J. Antagonistic fungi, Trichoderma spp.: Panoply of biological control. Biochem. Eng. J. 2007, 37, 1-20. [CrossRef]

2. Vinale, F.; Sivasithamparam, K.; Ghisalberti, E.L.; Marra, R.; Woo, S.; Lorito, M. Trichoderma-plant-pathogen interatctions. Soil Biol. Biochem. 2008, 40, 1-10. [CrossRef]

3. Benitez, T.; Rincon, A.M.; Limon, M.C.; Codon, A.C. Biocontrol mechanisms of Trichoderma strains. Int. Microbiol. 2004, 7, 249-260. [PubMed]

4. Elad, Y. Biological control of foliar pathogens by means of Trichoderma harzianum and potential modes of action. Crop. Prot. 2000, 19, 709-714. [CrossRef]

5. Zin, N.A.; Badaluddin, N.A. Biological functions of Trichoderma spp. for agriculture applications. Ann. Agric. Sci. 2020, 65, 68-178. [CrossRef]

6. Hermosa, R.; Viterbo, A.; Chet, I.; Monte, E. Plant-beneficial effects of Trichoderma and of its genes. Microbiology 2012, 158, 17-25. [CrossRef]

7. Luard, E.J.; Griffin, D.M. Effect of water potential on fungal growth and turgor. Trans. Br. Mycol. Soc. 1981, 76, 33-40. [CrossRef]

8. Magan, N. Effects of water potential and temperature on spore germination and germ-tube growth in vitro and on straw leaf sheaths. Trans. Br. Mycol. Soc. 1988, 90, 97-107. [CrossRef]

9. Knudsen, G.; Bin, L. Effects of temperature, soil moisture, and wheat bran on growth of Trichoderma harzianum from alginate pellets. Am. Phytopathol. Soc. 1990, 80, 724-727. [CrossRef]

10. Katan, J. Solar heating (solarization) of soil for control of soil-borne pests. Ann. Rev. Phytopathol. 1981, 19, 211-236. [CrossRef]

11. Tjamos, E.C.; Fravel, D.R. Detrimental effects of sublethal heating and Talaromyces flavus on microsclerotia of Verticillium dahliae. Phytopathology 1995, 85, 388-392. [CrossRef]

12. Tjamos, E.C.; Paplomatas, E.J. Long-term effect of soil solarization on Verticillium wilt of artichokes in Greece. Can. J. Plant. Pathol. 1987, 9, 87. 
13. Kumar, G.P.; Ahmed, S.K.M.H.; Desai, S.; Amalraj, E.L.D.; Rasul, A. In vitro screening for abiotic stress tolerance in potent biocontrol and plant growth promoting strains of Pseudomonas and Bacillus spp. Int. J. Bacteriol. 2014, $2014,195946$.

14. Alali, S.; Mereghetti, V.; Faoro, F.; Bocchi, S.; Al Azmeh, F.; Montagna, M. Thermotolerant isolates of Beauveria bassiana as potential control agent of insect pest in subtropical climates. PLoS ONE 2019, 14, e0211457. [CrossRef]

15. Poosapati, S.; Ravulapalli, P.D.; Tippirishetty, N.; Vishwanathaswamy, D.K.; Chunduri, S. Selection of high temperature and salinity tolerant Trichoderma isolates with antagonistic activity against Sclerotium rolfsii. SpringerPlus 2014, 3, 641. [CrossRef]

16. Shui, W.; Xiong, Y.; Xiao, W.; Qi, X.; Zhang, Y.; Lin, Y.; Guo, Y.; Zhang, Z.; Wang, Q.; Ma, Y. Understanding the mechanism of thermotolerance distinct from heat shock response through proteomic analysis of industrial strains of Saccharomyces cerevisiae. Mol. Cell Proteom. 2015, 14, 1885-1897. [CrossRef] [PubMed]

17. Wang, Z.X.; Zhou, X.Z.; Meng, H.M.; Liu, Y.J.; Zhou, Q.; Huang, B. Comparative transcriptomic analysis of the heat stress response in the filamentous fungus Metarhizium anisopliae using RNA-Seq. Appl. Microbiol. Biotechnol. 2014, 98, 5589-5597. [CrossRef]

18. Verghese, J.; Abrams, J.; Wang, Y.; Morano, K.A. Biology of the heat shock response and protein chaperones: Budding yeast (Saccharomyces cerevisiae) as a model system. Microbiol. Mol. Biol. Rev. 2012, 76, 115-158. [CrossRef]

19. Tereshina, V.M. Thermotolerance in fungi: The role of heat shock proteins and trehalose. Microbiology 2005, 74, 247-257. [CrossRef]

20. Montero-Barrientos, M.; Cardoza, R.E.; Gutiérrez, S.; Monte, E.; Hermosa, R. The heterologous overexpression of hsp23, a small heat-shock protein gene from Trichoderma virens, confers thermotolerance to T. harzianum. Curr. Genet. 2007, 52, 45-53. [CrossRef]

21. Montero-Barrientos, M.; Hermosa, R.; Nicolas, C.; Cardoza, R.E.; Gutlerrez, S.; Monte, E. Over expression of a Trichoderma HSP70 gene increases fungal resistance to heat and other abiotic stresses. Fungal Genet. Biol. 2008, 45, 1506-1513. [CrossRef]

22. Nicolas, C.; Hermosa, R.; Rubio, B.; Mukherjee, P.K.; Monte, E. Trichoderma genes in plants for stress tolerance- status and prospects. Plant. Sci. 2014, 228, 71-78. [CrossRef] [PubMed]

23. Delgado-Jarana, J.; Sousa, S.; Gonza 'lez, F.; Rey, M.; Llobell, A. ThHog1 controls the hyperosmotic stress response in Trichoderma harzianum. Microbiology 2006, 152, 1687-1700. [CrossRef] [PubMed]

24. Chatterjee, M.T.; Khalawan, S.A.; Curran, B.P. Cellular lipid composition influences stress activation of the yeast general stress response element (STRE). Microbiology 2000, 146, 877-884. [CrossRef]

25. Ram, A.F.; Arentshorst, M.; Damveld, R.A.; VanKuyk, P.A.; Klis, F.M.; den Hondel, C.A.V. The cell wall stress response in Aspergillus niger involves increased expression of the glutamine: Fructose-6-phosphate amidotransferase-encoding gene (gfaA) and increased deposition of chitin in the cell wall. Microbiology 2004, 150, 3315-3326. [CrossRef]

26. Chen, S.; Tarsio, M.; Kane, P.M.; Greenberg, M.L. Cardiolipin mediates cross-talk between mitochondria and the vacuole. Mol. Biol. Cell 2008, 19, 5047-5058. [CrossRef]

27. Konopka, J.B. N-acetylglucosamine (GlcNAc) functions in cell signaling. Scientifica 2012, 2012, 489208. [CrossRef]

28. Yang, P.; Du, H.; Hoffman, C.S.; Marcus, S. The phospholipase B homolog Plb1 is a mediator of osmotic stress response and of nutrient-dependent repression of sexual differentiation in the fission yeast Schizosaccharomyces pombe. Mol. Genet. Genom. 2003, 269, 116-125. [CrossRef] [PubMed]

29. Chauhan, N.; Latge, J.P.; Calderone, R. Signalling and oxidant adaptation in Candida albicans and Aspergillus fumigatus. Nat. Rev. Microbiol. 2006, 4, 435-444. [CrossRef]

30. Chauhan, N.; Calderone, R. Two-component signal transduction proteins as potential drug targets in medically important fungi. Infect. Immun. 2008, 76, 4795-4803. [CrossRef]

31. Colabardini, A.C.; Ries, L.N.A.; Brown, N.A.; Savoldi, M.; Dinamarco, T.M.; von Zeska, M.R.; Goldman, M.H.S.; Goldman, G.H. Protein Kinase C overexpression suppresses calcineurin-associated defects in Aspergillus nidulans and is involved in mitochondrial function. PLoS ONE 2014, 9, e104792. [CrossRef] [PubMed]

32. Abrams, J.L.; Verghese, J.; Gibney, P.A.; Morano, K.A. Hierarchical functional specificity of cytosolic heat shock protein 70 (Hsp70) nucleotide exchange factors in yeast. J. Biol. Chem. 2014, 289, 13155-13167. [CrossRef] [PubMed]

33. Gowda, N.K.; Kandasamy, G.; Froehlich, M.S.; Dohmen, R.J.; Andreasson, C. Hsp70 nucleotide exchange factor Fes1 is essential for ubiquitin-dependent degradation of misfolded cytosolic proteins. Proc. Natl. Acad. Sci. USA 2013, 110, 5975-5980. [CrossRef] [PubMed]

34. Kim, Y.; Nandakumar, M.P.; Marten, M.R. Proteome map of Aspergillus nidulans during osmoadaptation. Fungal Genet. Biol. 2007, 44, 886-895. [CrossRef] [PubMed]

35. Yin, Z.; Stead, D.; Walker, J.; Selway, L.; Smith, D.A.; Brown, A.J.P.; Quinn, J. A proteomic analysis of the salt, cadmium and peroxide stress responses in Candida albicans and the role of the Hog1 stress-activated MAPK in regulating the stress-induced proteome. Proteomics 2009, 9, 4686-4703. [CrossRef]

36. Imazu, H.; Sakurai, H. Saccharomyces cerevisiae heat shock transcription factor regulates cell wall remodeling in response to heat shock. Eukaryot. Cell 2005, 4, 1050-1056. [CrossRef]

37. Mota, T.M.; Oshiquiri, L.H.; Lopes, É.C.V.; Barbosa, F.J.R.; Ulhoa, C.J.; Georg, R.C. Hsp genes are differentially expressed during Trichoderma asperellum self-recognition, mycoparasitism and thermal stress. Microbiol. Res. 2019, 227, 126296. [CrossRef]

38. Dixit, P.; Mukherjee, P.K.; Ramachandran, V.; Eapen, S. Glutathione transferase from Trichoderma virens enhances cadmium tolerance without enhancing its accumulation in transgenic Nicotiana tobacum. PLoS ONE 2011, 6, e16360. [CrossRef]

39. Hermosa, R.; Botella, L.; Keck, M.; Jimenez, J.A.; Montero Barrientos, M.; Arbona, V.; Gomez Cadenas, A.; Monte, E.; Nicolas, C. The over expression in Arabidopsis thaliana of a Trichoderma harzianum gene that modulates glucosidase activity, and enhances tolerance to salt and osmotic stresses. J. Plant. Physiol. 2011, 168, 1295-1302. [CrossRef] 
40. Kusch, H.; Engelmann, S.; Albrecht, D.; Morschhauser, J.; Hecker, M. Proteomic analysis of the oxidative stress response in Candida albicans. Proteomics 2007, 7, 666-697. [CrossRef]

41. Liu, Y.; Solis, N.V.; Heilmann, C.J.; Phan, Q.T.; Mitchell, A.P.; Klis, F.M.; Filler, S.G. Role of retrograde trafficking in stress response, host cell interactions, and virulence of Candida albicans. Eukaryot. Cell 2014, 13, 279-287. [CrossRef] [PubMed]

42. Schmidt, P.; Walker, J.; Selway, L.; Stead, D.; Yin, Z.; Enjalbert, B.; Weig, M.; Brown, A.J.P. Proteomic analysis of the pH response in the fungal pathogen Candida glabrata. Proteomics 2008, 8, 534-544. [CrossRef] [PubMed]

43. Rey, M.; Llobell, A.; Monte, E.; Scala, F.; Lorito, M. Genomics of Trichoderma. In Applied Mycology and Biotechnology, Fungal Genomics; Khachatourians, G.G., Arora, D.K., Eds.; Elsevier BV: Amsterdam, The Netherlands, 2004; Volume 4, pp. $225-248$.

44. Vizcaíno, J.A.; González, F.J.; Suárez, M.B.; Redondo, J.; Heinrich, J.; Delgado-Jarana, J.; Hermosa, R.; Gutiérrez, S.; Monte, E.; Llobell, A.; et al. Generation, annotation and analysis of ESTs from Trichoderma harzianum CECT 2413. BMC Genom. 2006, 7, 193. [CrossRef] [PubMed]

45. Alfiky, A.; Weisskopf, L. Deciphering Trichoderma-Plant-Pathogen Interactions for Better Development of Biocontrol Applications. J. Fungi 2021, 7, 61. [CrossRef]

46. Druzhinina, I.S.; Seidl-Seiboth, V.; Herrera-Estrella, A.; Horwitz, B.A.; Kenerley, C.M.; Monte, E.; Mukherjee, P.K.; Zeilinger, S.; Grigoriev, I.V.; Kubicek, C.P. Trichoderma: The genomics of opportunistic success. Nat. Rev. Microbiol. 2011, 9, 749-759. [CrossRef]

47. Sharma, P.; Vignesh Kumar, P.; Ramesh, R.; Saravanan, K.; Deep, S.; Sharma, M.; Mahesh, S.; Dinesh, S. Biocontrol genes from Trichoderma species: A review. Afr. J. Biotechnol. 2011, 10, 19898-19907.

48. Srivastava, M.; Shahid, M.; Pandey, S.; Singh, A.; Kumar, V.; Gupta, S.; Maurya, M. Trichoderma Genome to Genomics: A Review. J. Data Min. Genom. Proteom. 2014, 5, 162. [CrossRef]

49. Atanasova, L.; Crom, S.L.; Gruber, S.; Coulpier, F.; Seidl-Seiboth, V.; Kubicek, C.P.; Druzhinina, I.S. Comparative transcriptomics reveals different strategies of Trichoderma mycoparasitism. BMC Genom. 2013, 14, 121. [CrossRef]

50. Rawlings, N.D.; Barrett, A.J.; Bateman, A. MEROPS: The database of proteolytic enzymes, their substrates and inhibitors. Nucleic Acids Res. 2012, 40, D343-D350. [CrossRef]

51. Suarez, M.B.; Vizcaino, J.A.; Llobell, A.; Monte, E. Characterization of genes encoding novel peptidases in the biocontrol fungus Trichoderma harzianum CECT 2413 using the TrichoEST functional genomics approach. Curr. Genet. 2007, 51, 331-342. [CrossRef]

52. Poosapati, S.; Ravulapalli, P.D.; Tippirishetty, N. Morphological and biochemical characterization of thermotolerant Trichoderma. Int. J. Curr. Res. 2016, 8, 38668-38672.

53. Jacobs, D.I.; van Rijssen, M.S.; van der Heijden, R.; Verpoorte, R. Sequential solubilization of proteins precipitated with trichloroacetic acid in acetone from cultured Catharanthus roseus cell yields 52\% more spots after two-dimensional electrophoresis. Proteomics 2001, 1, 1345-1350. [CrossRef]

54. Prieto, A.; Leal, J.A.; Poveda, A.; Jiménez-Barbero, J.; Gómez-Miranda, B.; Domenech, J.; Ahrazem, O.; Bernabé, M. Structure of complex cell wall polysaccharides isolated from Trichoderma and Hypocrea species. Carbohydr. Res. 1997, 304, 281-291. [CrossRef]

55. Perlińska-Lenart, U.; Orłowski, J.; Laudy, A.E.; Zdebska, E.; Palamarczyk, G.; Kruszewska, J.S. Glycoprotein hypersecretion alters the cell wall in Trichoderma reesei strains expressing the Saccharomyces cerevisiae dolichylphosphate mannose synthase gene. Appl. Environ. Microbiol. 2006, 72, 7778-7784. [CrossRef]

56. De Nobel, J.G.; van den Ende, H.; Klis, F.M. Cell wall maintenance in fungi. Trends Microbiol. 2000, 8, 344-345. [CrossRef]

57. Georg, R.C.; Gomes, S.L. Transcriptome analysis in response to heat shock and cadmium in the aquatic fungus Blastocladiella emersonii. Eukaryot. Cell 2007, 6, 1053-1062. [CrossRef] [PubMed]

58. Gilmore, S.A.; Naseem, S.; Konopka, J.B.; Sil, A. N-acetylglucosamine (GlcNAc) triggers a rapid, temperature-responsive morphogenetic program in thermally dimorphic fungi. PLoS Genet. 2013, 9, e1003799. [CrossRef] [PubMed]

59. Zhang, M.; Henquet, M.; Chen, Z.; Zhang, H.; Zhang, Y.; Ren, X.; van der Krol, S.; Gonneau, M.; Bosch, D.; Gong, Z. LEW3, encoding a putative alpha-1, 2-mannosyltransferase (ALG11) in N-linked glycoprotein, plays vital roles in cell-wall biosynthesis and the abiotic stress response in Arabidopsis thaliana. Plant. J. 2009, 60, 983-999. [CrossRef]

60. Damveld, R.A.; Franken, A.; Arentshorst, M.; Punt, P.J.; Klis, F.M.; van den Hondel, C.A.M.J.J.; Ram, A.F.J. A novel screening method for cell wall mutants in Aspergillus niger identifies UDP-galactopyranose mutase as an important protein in fungal cell wall biosynthesis. Genetics 2008, 178, 873-881. [CrossRef]

61. Zaccheo, O.; Dinsdale, D.; Meacock, P.A.; Glynn, P. Neuropathy target esterase and its yeast homolog degrade phosphatidylcholine to glycerophosphocholine in living cells. J. Biol. Chem. 2004, 279, 24024-24033. [CrossRef]

62. Romantsov, T.; Guan, Z.; Wood, J.M. Cardiolipin and the osmotic stress responses of bacteria. Biochim. Biophys. Acta 2009, 1788, 2092-2100. [CrossRef]

63. Feofilova, E.P.; Tereshina, V.M.; Khokhlova, N.S.; Memorskaya, A.S. Different mechanisms of the biochemical adaptation of mycelial fungi to temperature stress: Changes in the cytosol carbohydrate composition. Microbiology 2000, 69, 504-508. [CrossRef]

64. Grossklaus, D.D.; Bailao, A.M.; Rezende, T.C.V.; Borges, C.L.; de Oliveira, M.A.P.; Parente, J.A.; Soares, C.M.D. Response to oxidative stress in Paracoccidioides yeast cells as determined by proteomic analysis. Microbes Infect. 2013, 15, 347-364. [CrossRef]

65. Barelle, C.J.; Priest, C.L.; MacCallum, D.M.; Gow, N.A.; Odds, F.C.; Brown, A.J. Niche-specific regulation of central metabolic pathways in a fungal pathogen. Cell Microbiol. 2006, 8, 961-971. [CrossRef] [PubMed]

66. Lim, D.; Hains, P.; Walsh, B.; Bergquist, P.; Nevalainen, H. Proteins associated with the cell envelope of Trichoderma reesei: A proteomic approach. Proteomics 2001, 1, 899-909. [CrossRef] 
67. Yamamoto, A.; Mizukami, Y.; Sakurai, H. Identification of a novel class of target genes and a novel type of binding sequence of heat shock transcription factor in Saccharomyces cerevisiae. J. Biol. Chem. 2005, 280, 11911-11919. [CrossRef] [PubMed]

68. Desai, C.; Mavrianos, J.; Chauhan, N. Candida albicans SRR1, a putative two-component response regulator gene, is required for stress adaptation, morphogenesis, and virulence. Eukaryot. Cell 2011, 10, 1370-1374. [CrossRef]

69. Hashimoto, Y.; Perrino, B.A.; Soderling, T.R. Identification of an autoinhibitory domain in calcineurin. J. Biol. Chem. 1990, 265, 1924-1927. [CrossRef]

70. Vinnemeier, J.; Hagemann, M. Identification of salt regulated genes in the genome of the cyanobacterium Synechocystis sp. strain PCC 6803 by subtractive RNA hybridization. Arch. Microbiol. 1999, 172, 377-386. [CrossRef]

71. Mukhopadhyay, A.; He, Z.; Alm, E.J.; Arkin, A.P.; Baidoo, E.E.; Borglin, S.C.; Chen, W.; Hazen, T.C.; He, Q.; Holman, H.Y.; et al Salt stress in Desulfovibrio vulgaris Hildenborough: An integrated genomics approach. J. Bacteriol. 2006, 188, 4068-4078. [CrossRef]

72. Briolat, V.; Reysset, G. Identification of the Clostridium perfringens genes involved in the adaptive response to oxidative stress. J. Bacteriol. 2002, 184, 2333-2343. [CrossRef] [PubMed]

73. Rocak, S.; Linder, P. DEAD-box proteins: The driving forces behind RNA metabolism. Nat. Rev. Mol. Cell Biol. $2004,5,232-241$. [CrossRef] [PubMed]

74. Owttrim, G.W. RNA helicases and abiotic stress. Nucleic Acids Res. 2006, 34, 3220-3230. [CrossRef] [PubMed]

75. Ambrus, A.M.; Frolov, M.V. The diverse roles of RNA helicases in RNAi. Cell Cycle 2009, 8, 3500-3505. [CrossRef]

76. Linder, P.; Owttrim, G.W. Plant RNA helicases: Linking aberrant and silencing RNA. Trends Plant. Sci. 2009, 14, $344-352$. [CrossRef]

77. Jiao, X.; Xiang, S.; Oh, C.; Martin, C.E.; Tong, L.; Kiledjian, M. Identification of a quality control mechanism for mRNA $5^{\prime}$-end capping. Nature 2010, 467, 608-611. [CrossRef]

78. Malerba, M.; Crosti, P.; Cerana, R. Effect of heat stress on actin cytoskeleton and endoplasmic reticulum of tobacco BY-2 cultured cells and its inhibition by Co2+. Protoplasma 2009, 239, 23-30. [CrossRef]

79. Yang, J.; Everett, A.D. Hepatoma-derived growth factor binds DNA through the N-terminal PWWP domain. BMC Mol. Biol. 2007, 8, 101. [CrossRef]

80. Hahn, J.S.; Hu, Z.; Thiele, D.J.; Iyer, V.R. Genome-wide analysis of the biology of stress responses through heat shock transcription factor. Mol. Cell Biol. 2004, 24, 5249-5256. [CrossRef]

81. Pusztahelyi, T.; Klement, E.; Szajli, E.; Klem, J.; Miskei, M.; Karányi, Z.; Emri, T.; Kovács, S.; Orosz, G.; Kovács, K.L.; et al. Comparison of transcriptional and translational changes caused by long-term menadione exposure in Aspergillus nidulans. Fungal Genet. Biol. 2011, 48, 92-103. [CrossRef]

82. Druzhinina, I.S.; Shelest, E.; Kubicek, C.P. Novel traits of Trichoderma predicted through the analysis of its secretome. FEMS Microbiol. Lett. 2012, 337, 1-9. [CrossRef]

83. Hilt, W. Targets of programmed destruction: A primer to regulatory proteolysis in yeast. Cell Mol. Life Sci. 2004, 61, 1615-1632. [CrossRef]

84. Mori, K.; Kawahara, T.; Yoshida, H.; Yanagi, H.; Yura, T. Signalling from endoplasmic reticulum to nucleus: Transcription factor with a basic-leucine zipper motif is required for the unfolded protein-response pathway. Genes Cells 1996, 1, 803-817. [CrossRef] [PubMed]

85. Spear, E.D.; Ng, D.T.W. Stress tolerance of misfolded Carboxypeptidase $\mathrm{Y}$ requires maintenance of protein trafficking and degradative pathways. Mol. Biol. Cell 2003, 14, 2756-2767. [CrossRef]

86. Yen, W.; Shintani, T.; Nair, U.; Cao, Y.; Richardson, B.C.; Li, Z.; Hughson, F.M.; Baba, M.; Klionsky, D.J. The conserved oligomeric Golgi complex is involved in double-membrane vesicle formation during autophagy. J. Cell Biol. 2010, 188, 101-114. [CrossRef] [PubMed]

87. Whyte, J.R.; Munro, S. The Sec34/35 Golgi transport complex is related to the exocyst, defining a family of complexes involved in multiple steps of membrane traffic. Dev. Cell 2001, 1, 527-537. [CrossRef]

88. Ram, R.J.; Li, B.; Kaiser, C.A. Identification of Sec36p, Sec37p, and Sec38p: Components of yeast complex that contains Sec34p and Sec35p. Mol. Biol. Cell 2002, 13, 1484-1500. [CrossRef] [PubMed]

89. Bruinsma, P.; Spelbrink, R.G.; Nothwehr, S.F. Retrograde transport of the mannosyltransferase Och1p to the early Golgi requires a component of the COG transport complex. J. Biol. Chem. 2004, 279, 39814-39823. [CrossRef]

90. Oka, T.; Ungar, D.; Hughson, F.M.; Krieger, M. The COG and COPI complexes interact to control the abundance of GEARs, a subset of Golgi integral membrane proteins. Mol. Biol. Cell 2004, 15, 2423-2435. [CrossRef]

91. Zolov, S.N.; Lupashin, V.V. Cog3p depletion blocks vesicle-mediated Golgi retrograde trafficking in HeLa cells. J. Cell Biol 2005, 168, 747-759. [CrossRef]

92. Marcusson, E.G.; Horazdovsky, B.F.; Cereghino, J.L.; Gharakhanian, E.; Emr, S.D. The sorting receptor for yeast vacuolar carboxypeptidase $\mathrm{Y}$ is encoded by the VPS10 gene. Cell 1994, 77, 579-586. [CrossRef]

93. Boreham, D.R.; Trivedi, A.; Weinberger, P.; Mitchel, R.E. The involvement of topoisomerases and DNA polymerase I in the mechanism of induced thermal and radiation resistance in yeast. Radiat. Res. 1990, 123, 203-212. [CrossRef] [PubMed]

94. Perumal, S.S.; Shanthi, P.; Sachdanandam, P. Augmented efficacy of tamoxifen in rat breast tumorigenesis when gavaged along with riboflavin, niacin, and CoQ10: Effect on lipid peroxidation and antioxidants in mitochondria. Chem. Biol. Interact. 2005, 152, 49-58. [CrossRef] [PubMed] 
95. Sugiyama, M. Effects of vitamins on chromium (VI)-induced damage. Environ. Health Perspec. 1991, 92, 63-70. [CrossRef] [PubMed]

96. Horwitz, B.A.; Gressel, J. Elevated riboflavin requirement for post photoinductive events in sporulation of a Trichoderma auxotroph. Plant. Physiol. 1983, 71, 200-204. [CrossRef] [PubMed]

97. Kavitha, S.; Chandra, T.S. Effect of vitamin E and MD supplementation on riboflavin production and stress parameters in Ashbya gossypii. Proc. Chem. 2009, 44, 934-938.

98. Khan, M.R.; Parveen, G.; Zaid, A.; Wani, S.H.; Jogaiah, S. 5-Potential of Trichoderma species in alleviating the adverse effects of biotic and abiotic stresses in plants. In Biocontrol Agents and Secondary Metabolites; Woodhead Publishing: Sawston, UK, 2021; pp. 85-112. 